\title{
ERROR ANALYSIS ON UNINDRA STUDENT'S SENTENCE TENSES ASSIGNMENT
}

\author{
Sjafty Nursitti Maili \\ Program Studi Pendidikan Bahasa Inggris \\ Fakultas Bahasa dan Seni Universitas Indraprasta PGRI \\ Jl Nangka 58 Tanjung Barat, Jakarta Selatan, Indonesia \\ sjafty@gmail.com
}

\begin{abstract}
Knowing the pattern of tenses is very important to the students, because it can help them to do a good sentence. If the students unknown the pattern of using tenses in sentences, the students are confused to make a good sentence. The teacher should try to correct their error by error analysis. Error analysis is really very important to students, because teachers know the mistaken students done in making a sentence by using in each tenses. In this study, the researcher used descriptive method which is the data was taken by student's an assignment at the first students of UNINDRA. First, teachers asked students to make sentences based on eight tenses. They are Present Tense; Present Continuous Tense; Present Perfect Tense; Simple Future Tense; Past Tense; Past Continuous Tense; Past Continuous Tense; Past Perfect Tense; Future Perfect Tense. Second, After doing sentences in each tenses, the research done identify based on the pattern of sentences; Third, the last steps researcher analysis the assignment in make the table consist of table 1 the amount of error done; table 2 the error sentences students and correction; table 3 the reasons why sentences are difficulties to the students and easier. The results of these study 60 percentages students UNINDRA made good sentences in eight tenses; 40 percentages did not remember the pattern of tenses; 30 percentages made the error of changed verb; 30 percentages used time action to make sentence in each tenses.
\end{abstract}

Key words; Tenses, Assignment, Error, Analysis, Pattern

\begin{abstract}
Abstrak
Mengetahui formula tenses adalah amat penting dilakukan oleh siswa, karena itu sangat membantu didalam membuat kalimat yang baik. Apabila siswa - siswa tidak mengetahui formula dari penggunaan tenses didalam kalimat kemungkinan mereka bingung untuk membuat kalimat yang baik. guru harus mencoba untuk mengoreksinya melalui analisis kesalahan. Analisis kesalahan siswa sungguh- sungguh sangat penting, karena guru harus tahu kesalahan yang dilakukan didalam membuat kalimat yang baik didalam setiap tenses. Didalam penelitian ini, peneliti menggunakan metode deskripsi yang mana data diperoleh melalui tugas; Pertama, guru meminta siswa untuk membuat kalimat berdasarkan delapan tenses dalam bahasa Inggris; Present Tense; Present Continuous Tense; Present Perfect Tense; Simple Future Tense; Past Tense; Past Continuous Tense; Past Continuous Tense; Past Perfect Tense; Past Future Tense. Kedua, Sesudah melakukan kalimat didalam setiap tenses, peneliti melakukan identifikasi berdasarkan formula dari setiap tenses; Ketiga, langkah terakhir peneliti menganalisa tugas dan membuat tabel 1 jumlah kesalahan siswa; tabel 2 kesalahan kalimat siswa dan koreksi; tabel 3 alasan mengapa sulit dan mudah; Hasil dari study ini bahwa $600 \%$ siswa UNINDRA membuat kalimat yang baik didalam 8 tenses; $40 \%$ tidak mengingat formula dari setiap tenses. $30 \%$ membuat kesalahan perubaha kata kerja; $30 \%$ tidak memasukan keterangan waktu didalam setiap tenses.
\end{abstract}

Kata kunci; Waktu, Tugas, Kesalahan, Analisis, Formula

\section{INTRODUCTION}

English learning has undergone develop vastly. It can be seen English have taught an Elementary until
Faculty. There are some skills which is students should known and be the master of them. They are listening, speaking reading, and writing. The students at English department should 
know how to write in a good sentence because writing is one of the skills that students should be the master of it. Writing is one of difficult skills and According Rentaul, $S$ in her journal (2014; 152) stated writing is a medium of communication that represents language through the inscription of sign and symbols. In other words, writing is one competency should be had by an individual as an example giving aspiration, idea, etc. By using a good sentence making a person can be a master in grammar.

Grammar is a rule that the sentences structure in English so many and many is not made formula. The beginning of grammar shows playing of the formula but high grammar level playing of the feeling, and the formulas are relatives. That's why studying English directly on the skills and understanding of the structure automatically in mastering grammar. In general language in written have formal standard of the style language, if making a good writing need learn grammar.

Tenses are a part of the grammar. So, tenses are very important students to make a good sentence. Sentences consist of the words which are subject, verb, and object. Talking about sentences, they consist of simple and complete sentences. Simple sentences talk about the sentences which derived came from subject, verb. Subject is a person done something, and verb is an action of the subject, object is a person as the doer of the sentences. So when the students should make the sentences, the first they should know the pattern to make the sentences, if they know it, they are easy that making the sentences well, second, in English sentences related of the tenses, each tense has had a different pattern, for an examples present tense, past tenses are different pattern. The pattern of the tenses should students knew before. Each tense has have different pattern, it refer to time which the verb of each tense has undergone changing. According to Frank citied in Indra, Y (2012:251) stated that tense is special verb ending or accompanying auxiliary verbs signaling the time an event takes place. Hornby citied Indra, Y (2012:251) stated defines tense as any of he forms of the verb that may be used to indicate the time of the action or state expressed by the verb. In other words, tense has had the pattern and verb can be changed, so that it looked verb has have different form and difference in time.

Problems, the students are able to make the sentences in each tense but they forgot in making the sentences based on the pattern. Therefore, the students should know the pattern, so that they can know making good sentences in grammatical, they have to master in writing, and in this case they have to master an international language.

\section{Present Tense}

According to Cook and Suter in citied Indra, Y (2012; 251) stated the present tense indicates that something is taking place now. According to Azar, B (2002) The simple present says that something was true in the past, is true in the present, and will be true in the future.

Present Tense is made up of Subject + Verb1

Example: I study for two hours every night

She always drinks tea every morning

\section{Present Continuous Tense}

Simple Present Continuous Tense talks about an activity which in progressing at this time or now, for an example my father is watching TV right 
now. According to Azar, B(2002) stated the present countinous tense expresses an activity that is in progress at the moment of speaking.

Present Countinous Tense is made up of Subject+auxiliary be(am, is are)+Ving Example: He is attending the meeting I am watching television now

\section{Present Perfect Tense}

According to Azar,B (2002) stated The present perfect expresses the idea that something happened (or never happened)

Present Perfect Tense is made up of Subject + has/have $+V 3$

Examples: I have stayed in Jakarta for nine years

He has read that book

\section{Simple Future Tense}

Simple Future Tense talk about the activities in the future, it is not talked about in the present or past tense. The verb of the future tense can not be changed with verb 2 or verb 3 because it is not talked about in the past, and the pattern of the simple future tense was difference with present, past.

Simple Future Tense is made up of Subject+will+Verb1

Example: My father will go to Kalimantan next month

She will take the English course next month

\section{Past Tense}

Simple past tense expresses an activity which has done in the past. They began in the past and ended in the past. It is not refer to the activity in the present. Simple Past Tense has verb form adding ed at verb (watch + ed= watched) for regular verb, but the verb will not adding add the verb (makemade) for irregular verb. In generally, simple past tense expresses something happened in the past, it refers to definite time or specific time, for an example: My mother bought the present to my sister last week. Last week refer to the specific time in the past.

Past Tense is made up of the Subject $+V 2$

Example: I saw him three years ago

She bought a new car last week

\section{Past Continuous Tense}

According to Azar, B(2002) stated Past Countinous Tense two activities occurred at the same time, but one action began earlier and was in progress when the other action occurred.

Past Countinous Tense is made up of Subject+auxiliary be(was, were)+ving

Examples: I was studying when he was reading

When my mother called me. I was taking a shower

\section{Past Perfect Tense}

The Past Perfect Tense describes an activity which had happened before another time or before event happened in the past. The past perfect tense is formed with"had" and past participle for all subjects. Basically, past perfect tense talk an action completed in the past before another time or action in the past.

Past Perfect Tense is made up of Subject+ had+past participle

Example: I had never seen my old friend

When I arrived, the English teacher had just begun

\section{Future Perfect Tense}

According to Azar,B (2002) stated Future Perfect Tense expresses an activity that will be completed before another time or even in the future.

Future Perfect Tense is made up of Subject+will have+ Past Participle 
Example: I will have finished my study by the time I get married

She have worked hardly for six weeks

\section{Error Analysis}

In teaching learning process, the mistake is often made by the students, but as a teacher should try to make minimalist the mistake made of the students. Bartram and Walto in Asti, R defines mistakes as the inescapable fact of language learning (2002:11). According to Corder in Gustineva citied in Asti, R (2016; 3) explained that there are three causes of mistakes; transfer errors, overgeneralization, and error arising from the methods or material used in the teaching $(2007 ; 130-131)$. The mistake that happened repeatedly is called error. Corder in Gustineva in Asti, $\mathrm{R}$ noted that there are three functions of error; provide teacher with information about how much the learner had learnt, provide the researcher with evidence of how language was learnt, served as devices by which the learner discovered the rules of the target language $(2007 ; 124)$. In this study, the researcher chose error on students sentence tense assignment which is collected the assignment based on the Ellis (cited in Wang, 2008, p. 185) cited in Sillahi stated that presented some steps in analyzing errors including "collection of a sample of learner language, identification of errors, description of errors, explanation of errors, and error evaluation. There are many errors that using the tenses in making the sentences on students. By using error analyzing, it will do minimalist the error and help them to encourage the writing skill. Based on Ellis theories about some steps the errors and researcher followed to do error analysis students assignment tenses.

\section{METHODOLOGY RESEARCH}

This research used the descriptive methods which students make the sentence in writing based on the pattern, identified and analyzing. The researcher took the data from the first Semester students of UNINDRA. It is the basic structure for them.

There are some steps that the researcher took the data; First the researcher asked the students to make sentence based on the formula; second the researcher identified the sentences based on the formula in writing; Third, researcher analysis the sentence based on the formula.

\section{FINDING AND DISCUSSION}

Table 1.The amount of students' error

\begin{tabular}{clc}
\hline No & Grammar & $\begin{array}{c}\text { The amount } \\
\text { of students } \\
\text { error }\end{array}$ \\
\hline 1 & Present Tense & 7 \\
\hline 2 & $\begin{array}{l}\text { Present } \\
\text { Continues Tense }\end{array}$ & 4 \\
\hline 3 & $\begin{array}{l}\text { Present Perfect } \\
\text { Tense }\end{array}$ & 6 \\
\hline 4 & Future Tense & 7 \\
\hline 5 & Past Tense & 3 \\
\hline 6 & $\begin{array}{l}\text { Past Continuous } \\
\text { Tense }\end{array}$ & 3 \\
\hline 7 & $\begin{array}{l}\text { Past Perfect } \\
\text { Tense }\end{array}$ & 10 \\
\hline 8 & $\begin{array}{l}\text { Future Perfect } \\
\text { Tense }\end{array}$ & 18 \\
\hline
\end{tabular}

Based on the amount of error the students above, there are eight tenses researcher gave to the students. The purpose is to know how the student understood about the pattern of the tenses. Result of table above showed that students were confused about Future Perfect Tense; there are 18 errors 
from 27 students done the sentences. with errors for every Tenses. Below are students' sample sentences

Table 2. Error on students' sentences and Correction

\begin{tabular}{|c|c|c|c|}
\hline Tenses & Formula of tenses & Students Sentences & $\begin{array}{c}\text { Corrected students } \\
\text { sentence }\end{array}$ \\
\hline \multirow[t]{4}{*}{$\begin{array}{l}\text { Present } \\
\text { Tense }\end{array}$} & $\begin{array}{l}\text { Subject+Verb } 1+\mathrm{O}+\mathrm{Adv} \\
\text { of time }\end{array}$ & $\begin{array}{l}\mathrm{He} \text { is reading a } \\
\text { book }\end{array}$ & He reads a book \\
\hline & & $\begin{array}{l}\text { Rina go to school } \\
\text { everyday }\end{array}$ & $\begin{array}{l}\text { Rina goes to school } \\
\text { everyday }\end{array}$ \\
\hline & & $\begin{array}{l}\text { She eat apple every } \\
\text { morning }\end{array}$ & $\begin{array}{l}\text { She eats apple every } \\
\text { morning }\end{array}$ \\
\hline & & $\begin{array}{l}\text { Mother always take } \\
\text { care her child }\end{array}$ & $\begin{array}{l}\text { Mother always takes } \\
\text { care her child }\end{array}$ \\
\hline \multirow{3}{*}{$\begin{array}{l}\text { Present } \\
\text { Countinous } \\
\text { Tense }\end{array}$} & $\begin{array}{l}\text { Subject+To } \\
\text { be(am,is,are)+Verbing+ }\end{array}$ & $\begin{array}{l}\text { My mother and I } \\
\text { going to holiday }\end{array}$ & $\begin{array}{l}\text { My mother and I are } \\
\text { going to get holiday }\end{array}$ \\
\hline & & $\begin{array}{l}\text { Dimas doesn't } \\
\text { playing games when } \\
\text { I arrived }\end{array}$ & $\begin{array}{l}\text { Dimas is not playing } \\
\text { games when I was } \\
\text { arriving }\end{array}$ \\
\hline & & $\begin{array}{l}\text { I'll be home in an } \\
\text { hour }\end{array}$ & $\begin{array}{l}\text { I am arriving at } \\
\text { home for an hour. }\end{array}$ \\
\hline \multirow[t]{4}{*}{$\begin{array}{l}\text { Present } \\
\text { Perfect } \\
\text { Tense }\end{array}$} & $\begin{array}{l}\text { Subject+have/has+V3+ } \\
\text { Object }\end{array}$ & $\begin{array}{l}\text { You have given Mrs } \\
\text { sjafty's assignment } \\
\text { next morning }\end{array}$ & $\begin{array}{l}\text { You have given Mrs } \\
\text { sjafty's assignment } \\
\text { now. }\end{array}$ \\
\hline & & $\begin{array}{l}\text { I had gone with my } \\
\text { family on the } \\
\text { weekend }\end{array}$ & $\begin{array}{l}\text { I have gone with my } \\
\text { family right now }\end{array}$ \\
\hline & & $\begin{array}{l}\text { I have been gone to } \\
\text { Bali Island for three } \\
\text { times }\end{array}$ & $\begin{array}{l}\text { I have gone to Bali } \\
\text { for three times }\end{array}$ \\
\hline & & $\begin{array}{l}\text { He has left the } \\
\text { classroom a few } \\
\text { minutes ago }\end{array}$ & $\begin{array}{l}\text { He has left the } \\
\text { classroom for a few } \\
\text { minutes ago }\end{array}$ \\
\hline \multirow[t]{2}{*}{$\begin{array}{l}\text { Future } \\
\text { Tense }\end{array}$} & $\begin{array}{l}\text { Subject+will+V1+Objec } \\
\text { t+Adv of time }\end{array}$ & $\begin{array}{l}\text { They are going to } \\
\text { come }\end{array}$ & $\begin{array}{l}\text { They are going to } \\
\text { come tomorrow }\end{array}$ \\
\hline & & $\begin{array}{l}\text { She will have } \\
\text { graduated from } \\
\text { Seniour High School } \\
\text { next year }\end{array}$ & $\begin{array}{l}\text { She will graduate } \\
\text { from Seniour High } \\
\text { School next month }\end{array}$ \\
\hline
\end{tabular}




\begin{tabular}{|c|c|c|c|}
\hline & & $\begin{array}{l}\text { I will regret for this } \\
\text { I will visited them in } \\
\text { hospital }\end{array}$ & $\begin{array}{l}\text { I will be regret for } \\
\text { this } \\
\text { I will visit them in } \\
\text { hospital next moth }\end{array}$ \\
\hline & & $\begin{array}{l}\text { Ema going to go to } \\
\text { mall }\end{array}$ & $\begin{array}{l}\text { Ema is going to go } \\
\text { to mall }\end{array}$ \\
\hline Past Tense & $\begin{array}{l}\text { Subject+V2+Object+Ad } \\
\text { v Of time }\end{array}$ & $\begin{array}{l}\text { He send me a } \\
\text { bouquet of flower }\end{array}$ & $\begin{array}{l}\text { He sent me a } \\
\text { bouquet of flower } \\
\text { last week }\end{array}$ \\
\hline & & $\begin{array}{l}\text { He maked a juice } \\
\text { together with my } \\
\text { friend }\end{array}$ & $\begin{array}{l}\text { He made a juice } \\
\text { together with my } \\
\text { friend }\end{array}$ \\
\hline & & She want to school & $\begin{array}{l}\text { She went to school } \\
\text { yesterday morning }\end{array}$ \\
\hline & & $\begin{array}{l}\text { Raden visit to Riau } \\
\text { last month }\end{array}$ & $\begin{array}{l}\text { Raden visited to } \\
\text { Riau last month }\end{array}$ \\
\hline $\begin{array}{l}\text { Past } \\
\text { Continuous } \\
\text { Tense }\end{array}$ & $\begin{array}{l}\text { Subject+am,is,are+Ving } \\
+ \text { object+Adv of time }\end{array}$ & $\begin{array}{l}\text { My friends was } \\
\text { going to campus on } \\
\text { bus }\end{array}$ & $\begin{array}{l}\text { My friends were } \\
\text { going to campus on } \\
\text { bus }\end{array}$ \\
\hline & & $\begin{array}{l}\text { I was making a cake } \\
\text { in the kitchen with } \\
\text { my mother and my } \\
\text { friend come to my } \\
\text { house }\end{array}$ & $\begin{array}{l}\text { I was making a cake } \\
\text { with my mother in } \\
\text { the kitchen when my } \\
\text { friend came to my } \\
\text { house }\end{array}$ \\
\hline & & $\begin{array}{l}\text { You were always } \\
\text { wearing my shoes } \\
\text { last week }\end{array}$ & $\begin{array}{l}\text { You were wearing } \\
\text { my shoes while I } \\
\text { was arriving at home }\end{array}$ \\
\hline $\begin{array}{l}\text { Past } \\
\text { Perfect } \\
\text { Tense }\end{array}$ & Subject+had+V3 & $\begin{array}{l}\text { Mery had been made } \\
\text { her assignment } \\
\text { before rina came to } \\
\text { her house }\end{array}$ & $\begin{array}{l}\text { Mery had made her } \\
\text { assignment before } \\
\text { rina came to her } \\
\text { house. }\end{array}$ \\
\hline $\begin{array}{l}\text { Future } \\
\text { Perfect } \\
\text { Tense }\end{array}$ & Subject+will+have+V1 & $\begin{array}{l}\text { I will have finished } \\
\text { my homework. }\end{array}$ & $\begin{array}{l}\text { I will have finish my } \\
\text { homework by the } \\
\text { time I go to campus } \\
\text { on a date tonight }\end{array}$ \\
\hline $\begin{array}{r}\text { The err } \\
\text { can be showe }\end{array}$ & $\begin{array}{l}\text { or on students' assignment } \\
\mathrm{d} \text { in table } 2 \text { and the result }\end{array}$ & $\begin{array}{r}\text { Table 3. Reasol } \\
\mathrm{s}\end{array}$ & $\begin{array}{l}\text { s of difficulty students } \\
\text { entences }\end{array}$ \\
\hline is many stuc & lents had been made an & Students & Reasons \\
\hline error when th & word changed verb. & Students 1 & $\begin{array}{l}\text { am still confused in } \\
\text { ast Perfect Tense }\end{array}$ \\
\hline & & Students 2 & t's quit easy for me, \\
\hline
\end{tabular}




\begin{tabular}{|c|c|}
\hline & $\begin{array}{l}\text { especially past perfect } \\
\text { tense }\end{array}$ \\
\hline Stud & It's easy for me \\
\hline Studer & $\begin{array}{l}\text { I am still confused to } \\
\text { make the sentence }\end{array}$ \\
\hline Stud & $\begin{array}{l}\text { I am able to make the } \\
\text { sentences in each } \\
\text { tenses }\end{array}$ \\
\hline Stud & $\begin{array}{l}\text { I understand the } \\
\text { pattern for each tenses }\end{array}$ \\
\hline$\overline{\text { Stud }}$ & $\begin{array}{l}\text { I think an exercising is } \\
\text { not really difficult } \\
\text { because this is basic of } \\
\text { structure. }\end{array}$ \\
\hline Stu & $\begin{array}{l}\text { I can't make a good } \\
\text { sentences because I } \\
\text { forget the formula and } \\
\text { vocabulary }\end{array}$ \\
\hline Stud & $\begin{array}{l}\text { I think to make } \\
\text { sentences are easy }\end{array}$ \\
\hline Stuc & $\begin{array}{l}\text { I always forget about } \\
\text { formula }\end{array}$ \\
\hline Stuc & $\begin{array}{l}\text { I am still confused } \\
\text { about the tenses }\end{array}$ \\
\hline Stuc & $\begin{array}{l}\text { I don't know about } \\
\text { Verb } 1 \text { and verb } 3\end{array}$ \\
\hline Stuc & $\begin{array}{l}\text { understood about } \\
\text { Present Perfect and } \\
\text { Past Perfect }\end{array}$ \\
\hline Stud & $\begin{array}{l}\text { Basically I just know a } \\
\text { little bit of structure }\end{array}$ \\
\hline Stu & $\begin{array}{lll}\text { I'm still confused } \\
\text { about } \\
\text { tenses }\end{array}$ \\
\hline 16 & It's a little difficulty \\
\hline Stud & I forget all the tenses \\
\hline Stud & $\begin{array}{l}\text { I always forget the } \\
\text { formula, so I don't } \\
\text { understand to write } \\
\text { sentence }\end{array}$ \\
\hline Students 19 & $\begin{array}{l}\text { It's difficulty for me } \\
\text { because I can't choose } \\
\text { a good vocabulary for } \\
\text { the sentences }\end{array}$ \\
\hline Students 20 & $\begin{array}{l}\text { I think it is not } \\
\text { difficulty because I } \\
\text { have already known }\end{array}$ \\
\hline
\end{tabular}

\begin{tabular}{ll}
\hline & $\begin{array}{l}\text { and remembered about } \\
\text { formula. }\end{array}$ \\
\hline Students 21 & $\begin{array}{l}\text { I sometimes have no } \\
\text { an idea to make the } \\
\text { sentences in tenses }\end{array}$ \\
\hline Students 22 & $\begin{array}{l}\text { I understood in making } \\
\text { sentences tenses }\end{array}$ \\
\hline Students 23 & $\begin{array}{l}\text { I always make a } \\
\text { mistake in using } \\
\text { tenses. }\end{array}$ \\
\hline Students 24 & $\begin{array}{l}\text { I was confused about } \\
\text { Past Continuous } \\
\text { Tense, Present Perfect, } \\
\text { and Future Perfect } \\
\text { Tense }\end{array}$ \\
\hline Students 25 & $\begin{array}{l}\text { I often forget the } \\
\text { formula, so it is hard }\end{array}$ \\
\hline Students 26 & $\begin{array}{l}\text { It's easy, I have } \\
\text { understood since I got } \\
\text { Integrated } \\
\text { subject }\end{array}$ \\
\hline Students 27 & $\begin{array}{l}\text { I think It's quit easy } \\
\text { but not all because I } \\
\text { still confused in using } \\
\text { Past Perfect and Future } \\
\text { Perfect Tense and } \\
\text { Forget the formula of } \\
\text { tenses }\end{array}$ \\
\hline & \\
&
\end{tabular}

The table above showed why the students made mistake to make sentence well in each tenses. They said that making a good sentences by using the pattern is difficulty if they unknown the pattern of sentences in each tenses.

Table 4. The amount of students error and Quiz students score

\begin{tabular}{|c|c|c|}
\hline Student & $\begin{array}{ll}\text { Amount } & \text { of } \\
\text { errors } & \text { in } \\
\text { writing } & \\
\text { assignment } & \text { for } \\
\text { tenses } & \\
\end{array}$ & $\begin{array}{l}\text { Quiz } \\
\text { score }\end{array}$ \\
\hline Student 1 & 2 & 65 \\
\hline Student 2 & 1 & 80 \\
\hline Student 3 & 1 & 80 \\
\hline Student 4 & 2 & 70 \\
\hline Student 5 & 2 & 75 \\
\hline Student 6 & 2 & 80 \\
\hline
\end{tabular}




\begin{tabular}{ccc}
\hline Student 7 & 2 & 73 \\
\hline Student 8 & 4 & 76 \\
\hline Student 9 & 4 & 77 \\
\hline Student 10 & 4 & 71 \\
\hline Student 11 & 2 & 77 \\
\hline Student 12 & 5 & 69 \\
\hline Student 13 & 2 & 76 \\
\hline Student 14 & 4 & 73 \\
\hline Student 15 & 2 & 69 \\
\hline Student 16 & 2 & 69 \\
\hline Student 17 & 2 & 71 \\
\hline Student 18 & 3 & 69 \\
\hline Student 19 & 2 & 73 \\
\hline Student 20 & 2 & 69 \\
\hline Student 21 & 2 & 80 \\
\hline Student 22 & 5 & 70 \\
\hline Student 23 & 5 & 80 \\
\hline Student 24 & 2 & 79 \\
\hline Student 25 & 3 & 69 \\
\hline Student 26 & 1 & 80 \\
\hline Student 27 & 4 & 69 \\
\hline
\end{tabular}

Based on the table 4 above, there are twenty seven students has followed QUIZ, it was done when students followed the fourth times meeting, and gave them the quiz. The table showing that only one of twenty seven of students got below 70, and other students has done well, so the students learnt from the error based on they had done when they would be followed the quiz, it can be easy to do it. Basically, the students had known making the sentences but some of the students said they their description in table 3 students $3,6,9,14$ stated that she felt that she did not make a good sentences but in the table 4 they have done well, students 3 got of score 80, students 6 got 80 , students 9 got 77 , and students 14 got 73 too.

Table 5. The top of eight Tenses students error

\begin{tabular}{clcc}
\hline Number & \multicolumn{2}{c}{ Tenses } & $\begin{array}{c}\text { Amount } \\
\text { of error }\end{array}$ \\
\hline 1 & $\begin{array}{l}\text { Future } \\
\text { Tense }\end{array}$ & Perfect & 18 \\
\hline
\end{tabular}

\begin{tabular}{clc}
\hline 2 & $\begin{array}{l}\text { Past Perfect } \\
\text { Tense }\end{array}$ & 10 \\
\hline 3 & Present Tense & 7 \\
\hline 4 & Future Tense & 7 \\
\hline 5 & $\begin{array}{l}\text { Present } \\
\text { Continues Tense }\end{array}$ & 4 \\
\hline 6 & $\begin{array}{l}\text { Past Continuous } \\
\text { Tense }\end{array}$ & 3 \\
\hline 7 & Past Tense & 3 \\
\hline
\end{tabular}

The biggest number on Future Perfect Tense is very difficult to students done it. The table above showed that Future Perfect Tense and Past Perfect Tense are hardest topic to students understand and apply in the sentences.

\section{CONCLUSION}

Understanding the patterns of tenses is more effectively to students in making the sentence than students unknown the pattern. First, by knowing the pattern the students are able to know and do the sentences well. Even though, the students have had much vocabulary if they don't know the pattern of each tenses sentences, they are confused making a good sentences. Second, based on the result of the analysis above we conclude that $70 \%$ students felt easy to make the sentences because they knew the pattern of each tenses used. 30 $\%$ stated than they were difficult to make the sentences in each tenses because they did not know the pattern of the tenses. The big an error of assignment students' sentence is in the past future tense because they do not know the pattern.

As the teacher should corrected the sentences if the students made a mistake because it can help students to know what is right and the wrong. According to Wang (2008) citied in Silalahi, R stated that the teachers were given a primary responsibility to 
analyze students 'error because they were worth studying in order to help students learned more comfortably and without pressures of being marked wrong but being encouraged for the positive comments they got from their teacher."

\section{REFERENCES}

George, E. (1980). Wishon \& Julia M. Burks. Let's Write English. Litton Educational Publishing International 135 West $50^{\text {th }}$ Street New York 10020 U.S.A.

Indra, Y. (2012). A Correlation Between Students; Mastery Of Past Tense And Their Achievement In Writing Recount. Globish. An English Indonesian Journal For English Education And Culture. English
Department Faculty of

Education and Teacher

Trainning University Of

Muhammadiyah Tangerang.

Ramadhani, A. (2016). Correction of

Grammatical Mistakes in

Classroom Interaction. DEIKSIS

Journal. University Of

Indraprasta PGRI Jakarta.

Silalahi, R. (2014). Error Analysis on Information and Technology Students' Sentence Writing Assignment. IJEE Journal. Faculty of Tarbiyah and Teachers Trainning UIN Syarif Hidayatullah Jakarta.

Wang, P. (2008). Exploring Errors in Target Language Learning and Use; Practice meets Theory, English Language teaching, 1(2).

182-187 